\title{
12 Using building requirements as a means to create inclusion
}

\author{
Accessibility and usability at a crossroads
}

Jonas E. Andersson

Universal design implies that society is conceived with awareness of the population's diversity, and that people with disabilities can take part in activities of everyday life on equal terms with people without disabilities.

(Proposition, 2016/17: 188, p. 28)

In 2017, the Swedish government redefined the national goal for the disability policy based on the United Nations Convention on the Rights of Persons with Disabilities (CRPD). The goal was to 'achieve egalitarian living conditions and full participation for people with disabilities in society' along with increased gender equality and respect of children's rights (ibid.: p. 22). This redefinition was justified since the previous formulation of the goal had dated back to the ideological landscape of the early 1990s, i.e., prior to the introduction of the convention in Sweden in 2008. The new disability policy provides four means of achieving this goal:

1 Preventing and counteracting discrimination;

2 Suggesting individualised solutions and support to expand and maintain individual independence;

3 Addressing existing deficiencies in accessibility; and

4 Implementing the principle of universal design.

The new disability policy takes the fourth of these, universal design (Story et al., 2011), as the strategic point of departure for the full policy programme. Universal design thus influences the other three key areas. Although the concept of universal design is generally little known, the Swedish government does not see it necessary to implement new regulations to promote its implementation. Instead, the policy suggests an overhaul of existing legislation and regulations for the built environment, targeting easily eliminated obstacles and the inclusion of disability policy into municipal and regional physical planning (Proposition, 2016/17: 188, pp. 64-65).

The principle of universal design is a prioritised dimension in the realisation of the national disability policy. Following the motto of being a DOI: $10.4324 / 9781003120452-16$ 
country that keeps together, the modern welfare state shall be conceived in such a manner that all citizens can be part of it to the largest extent possible. This increases the possibility for society to promote accessibility and participation for people with disabilities.

(Proposition, 2016/17: 188, p. 28)

Consequently, the new disability policy is closely linked to building legislation and fundamental parameters for the conception of new building designs or for refurbishing existing ones. Universal design thinking is promoted as a principle, a method and a process for minimising risks due to inadequate physical planning and programming of new buildings (SOU, 2019: 23). It is debatable whether the new disability policy will strengthen or weaken the necessary linkages between the accessibility-usability oriented perspective of the previous building act with appurtenant regulations and the brand-new concept universal design in the new disability policy (see also Hanna Egard's chapter in this book).

\section{Disability policies and building acts}

In contrast to the new disability policy of 2017, the policy during the 2000-2010 period had a direct impact on the building act. This resulted in the formulation of two new regulations covering a new area of building regulation. These are still in use and cover existing buildings and public spaces in the townscape, and aim at removing conflicts between users and the realisation of the built space. In the previous policy, such conflicts were termed 'easily eliminated' obstacles. The concept continues to thrive, since the very nature of such problems is that they often are persistent due the slower pace of change in the built environment (see also David Wästerfors' chapter in this book). These obstacles can be found in exterior access points to public buildings, in public outdoor spaces as well as in the interiors of buildings.

The Swedish building act promotes user-friendly design in the built environment and long-term sustainable buildings and building practices. Requirements on accessibility are mandatory for any developer for both new and refurbished building projects. The building act places the full responsibility for the fit between future user groups of the building and the architectural design onto the developer. In the absence of real users, for good or ill, building experts like architects and engineers often act as proxies by drawing on their own experiences and preferences.

After Sweden ratified the CRPD in 2008, the building act was reformed once again. To highlight the relationship between the users of the built environment and the physical design of the building, the existing concept of accessibility was converted into something more user-oriented through new twin criteria of usability and accessibility for buildings and physical planning. These provoked little reaction in the Swedish building industry. 
However, shortly after these changes to the building act with appurtenant regulations, the building industry started to link Swedish housing shortages with what it labelled the too-far-reaching mandatory requirements of the building act (Nohrstedt, 2009). The Swedish construction company JM AB, one of the country's three largest, with projects in Sweden, Scandinavia and the European Union, condemned the act's accessibility requirements as the key factor in why building costs in Sweden had skyrocketed (Fock, 2010). Three years later, the construction company NCC AB, with a similar portfolio of building projects, presented a report suggesting that the building act was the cause of the national housing crisis (NCC, 2012). The report claimed that it was not only the accessibility-usability requirements but also the legal mechanisms of the system that controls comprehensive physical planning, building design and building permits that had resulted in longer preparatory processes and higher building costs in Sweden than in identical projects in other countries (ibid.).

\section{Aims and purposes}

The promotion of universal design to the highest priority area in disability policy challenges the established dynamics of the accessibility-usability requirements of the Swedish building act. At the same time, critiques of the building act, as well as the substantial cost and time implications of accessibility-usability requirements, threaten the realisation of this new goal. The present study is focused on the background of the current building act as a promoter of inclusion for people with disabilities and the conflicts that may arise when national disability policy appears out of step with ongoing reforms to the building act with appurtenant building regulations. This study explores a phenomenon situated in two research fields which are often seen as unrelated - the rights of people with disabilities and technical requirements for building - using a case study methodology (Flyvbjerg, 2004; Yin, 2003). The study focuses on reforms of the Swedish building act that occurred between 1930 and 2020.

The research material was assembled through keyword searches in open and restricted databases for words in both English and Swedish related to access, accessibility, usability, disabilities or handicap, inclusion and participation. Given the nature of building design and physical planning, i.e., as an acquired theoretical knowledge put in continuous practice depending on the assignment and the commissioner (Cold et al., 1992; Schön, 1988), the accumulated research material consisted of research papers and grey literature including exemplary buildings, professional magazines and governmental reports and guidelines. The material was analysed with an intersectional perspective that used the dichotomy between the fully abled body's abilities versus perceptions of the disabled body's abilities, congenital or acquired disabilities (Hill Collins \& Bilge, 2020; Norris et al., 2007). The reading focused on building requirements that are of relevance for promoting an appropriate fit between people with disabilities and the built environment, e.g., width of passage, horizontal and vertical communication, gradients and different levels. 


\section{A short overview of the Swedish building legislation}

Given the relatively slow pace of change in the built environment, existing buildings often solidify past or present views on the relationship between architectural design and the user (Gieryn, 2002). Hospitals and institutions accommodating people cared for through societal means often demonstrate a control mechanism that is present in the architectural configuration of the building (Foucault, 1975; Goffman, 1961). Sweden together with Canada and Denmark are often hailed as one of the best countries in the world at promoting equal rights for people with disabilities and the accessibility and usability of the built environment (Fardeau, 2015). In Sweden like other countries that have included minimum requirements in their building acts rather than in discrimination legislation, the evolution of the modern accessibility requirements in national building acts, national standards or international standards can be studied in real-life settings by exploring modern building design. A common trait of such requirements is the use of biometric data for human beings of different ages and of various abilities to define the minimum measurements for door width, corridor width, threshold height and ramp gradients in guidelines, norms and standards.

In its opening paragraph, the Swedish Planning and Building Act declares that the legal framework aims at "promoting a societal development with appropriate and equal living conditions for all as well as a progression towards a sustainable environment for present generations and future ones' (SFS, 2010:900, §1). The Swedish building legislation, like in most Scandinavian countries (except Norway), is typically focused on the concept of 'accessibility and usability' rather than 'universal design' (Dion et al., 2015). Already in the programming phase of a new or a refurbished building, conditions for people with disabilities accessing or egressing the building must be evaluated in terms of safety and security for all users by realising certain minimum requirements for accessibility and usability, i.e. physical measurements and spatial configurations for ease of use. The regulations act in two ways: as a design parameter for conceiving the architectural design, and as a technical parameter for the construction of a new or refurbished building.

Compliance with the building act and appurtenant regulations is monitored and supervised by the municipal administration: first, during the building permit phase, and, second, during the construction phase, through a control plan that targets requirements such as accessibility and usability, construction, hygiene and indoor climate and fire safety. This planning will be decisive for future users of the buildings, affecting their sense of safety and security in case of exceptional conditions (see also Kristofer Hansson's chapter in this book). Swedish accessibility and usability requirements are traceable through a series of reforms of the national building act from 1930 to the present day, in parallel with the definition of the national disability or housing policy. A common feature of these reforms is the intention to promote a better national housing standard with improved living conditions. 
Under the Swedish principles of civil administration, reforms are prepared by special committees designated by the Swedish Parliament or the Swedish government. These committees explore their assignment through one or several reports. During or at the end of the committee work, the reports enter a consultation process during which opinions are assembled concerning the proposals. These opinions are then considered by parliament or the government and assessed by a legal counsel before being further developed as a parliamentary or governmental bill. This process gives valuable insight into the underlying beliefs or mechanisms that may influence the final orientation of a reform.

\section{The roots of today's inclusive built environment}

To understand the emergence of accessibility as a building requirement in Sweden, we must first revisit the early twentieth century. At the time, Sweden ranked among the poorest European countries, with a steady flow of emigrants hoping to build a better life in the United States (Åman, 1976). The country was slowly changing from a predominantly agrarian society into a modern industrialised society. In both rural and urban areas, housing standards were poor, with overcrowded dwellings, inadequate heating and hygiene installations, sanitation or access to running water. The building act of the time was out of pace with the ongoing changes in Swedish society (Nordlander Finn, 1994). An increasing proportion of the rural population left the countryside to find work in industries in the growing cities. Large landowners, along with a rudimentary system for physical planning, hindered the development of new urban settlements with improved housing. The building professions - architects, engineers and builders - had little knowledge about the spatial needs of the growing working-class population (ibid.). Financial and rational building motives determined the layout of new housing for this group.

Social matters concerning children, older people and people with disabilities were discussed both nationally and in collaboration with other Nordic states, for instance, at a large conference held in Stockholm in 1906. While the rest of Europe was involved in World War I, the neutral Nordic countries organised exhibitions on appropriate furniture and housing for the working class; these were held, for example, in Copenhagen in 1917 and 1918. The fin-de-siècle liberal and social-democratic movement largely adhered to the belief that the architectural design of buildings and physical planning are factors that mould the achievement of societal visions. A social hierarchy was detectable in the configuration of the built space. Accommodation for people with special characteristics - the dependent elderly, or those living with disabilities, in orphanages or who experienced work-related injuries and sickness relied on large-scale institutions that separated such groups from the wider population. Run by parishes or benevolent organisations, the institutions were characterised by a strict division between men and women, with separate dormitories, seating arrangements in canteens, workspaces and 
chores (Åman, 1976). The institutions turned into profit-generating sites in which childcare, education, eldercare, housing and work opportunities were provided under poor living conditions (ibid.). Seen from a building perspective, the architectural design of these large institutions promoted the introduction of new building techniques, building materials and the programming of built space. Central heating and hygienic installations - water closets and running hot and cold water - became integral building parts (Kolstrup, 1996).

Inspired by Florence Nightingale's requirement of a 'cubicle' of fresh air around the bed of each patient, ventilation techniques for distributing fresh air inside built spaces started to evolve to promote good health among the inhabitants. The emphasis on fresh air and daylight led to larger and more spacious buildings. The older miasma theory, about the lethal influence of bad air on human health, started to give way to the emerging new sciences of bacteriology, medicine, nursing and virology. In 1918, the poor relief act was reformed and supplemented with architectural drawings of prototypes for old people's homes, orphanages and other institutions for children and adolescents (Civildepartementet, 1920). The architectural drawings aimed to create more humane living conditions and even a homelike atmosphere (ibid.). The buildings met minimum requirements and were strictly calculated to meet restricted budgets and be eligible for state grants.

The overturn of the old order caused by World War I led to an architectural reorientation in Europe which promoted a sociological approach to building and physical planning by the end of the 1920s (Lundberg \& Tydén, 2010). Architectural design increasingly focused on the fit between user needs and the built environment and, to some extent, was influenced by increased societal support (ibid.). In Sweden, building prototypes promoted by the political fin de siècle movement were closely analysed and heavily criticised for their inadequate fit between users and spatial configuration (Göransson \& Sundbärg, 1933).

\section{New ideals: housing that emphasised user-based knowledge}

By the end of the 1920s, the Swedish social-democratic movement had gained momentum. In a speech to the Swedish Parliament in 1928, the social democratic politician Per Albin Hansson introduced the concept of Folkhemmet as an ideal for the development of the modern Swedish welfare model: 'equality, mutual consideration, cooperation, and kindness persist in the good home environment' (Hansson, 1928). The Stockholm Exhibition of 1930, about architecture, arts and crafts, solidified this meaning by its focus on 'furnishings for small modern apartments, making the furniture adjustable to different uses and arrangement, while keeping high ideals of beauty, comfort, and fitness of material' and aiming for 'pleasant and practical homes for the people of average income' (Hong Rutt, 1933). This Swedish take on new housing and the home environment was less radical than the modernistic 
Bauhaus architecture and art in the German Weimar republic, and was based on the art and crafts movement of the late nineteenth century (Eriksson, 2001; Hong Rutt, 1933; Rudberg, 1999). It emphasised a holistic approach, which promoted a fit between human needs, building design and other artefacts in harmony with past aesthetic paradigms and the potential of industrial mass production (ibid.). Although criticised for being 'simplistic', functionalist architecture was integrated into the Folkhemmet, with an everlasting imprint on twentieth century architecture and planning in Sweden (Rudberg, 1999).

Amidst the social problems of the early 1930s - crammed housing and housing shortages, demographic and social change and ongoing urbanisation - the Stockholm Exhibition sought to find new solutions for housing, furniture and housing equipment. The configuration of the individual habitat was defined, with separate bedrooms for couples, children and singles. Space for storage and laundry was introduced. New concepts for kitchens with space for eating were introduced as well as a special space for socialising: the living room. Lifts were installed to transport people or for services such as meal delivery. Prefabrication and modular systems for building were introduced. Anticipating the introduction of the two-week paid summer vacation in 1938, prefabricated wooden modules for holiday homes were put on display. These envisioned a fit between architectural design and the individual user revolving around traditional family values: a married couple with the wife at home, husband outside the home, and two children. The exhibition had an inspirational effect on Swedish architecture, and opened up the view of the home as a machine, and thereby also embraced new ideas about different family constellations and employment for women (Asplund et al., 1931). Consequently, individual dwellings were combined with communal services for co-housing with integrated restaurants and other services. Participatory design processes for architecture were also developed.

However, the common denominator in the architectural designs and objects presented at the Stockholm Exhibition was a focus on the fit between people enjoying the capacities of a fully abled body and the built environment (Rudberg, 1999). People with disabilities were not an intended group of users and they, and other user profiles, were assumed to be living in institutional environments (Bergh, 1996). While having a much more limited impact, alternative ways of living outside the institutions were on the agenda of the organisations defending the rights of people with disabilities that had been formed at the end of the nineteenth and the first half of the twentieth century. At the top of their agenda was inclusion on equal terms with the rest of the population (Persson Bergvall \& Sjöberg, 2012). The Swedish association for visually impaired people (in Swedish Synskadades Riksförbund, SRF) picked up the new tendencies in architectural thinking. The association promoted an architectural design that integrated user needs, giving architecture a supportive character and including features like handrails, colour cues, tactile cues and appropriate room sizes (see Figure 12.1). New housing concepts and participatory design processes in the new settlements developed by the association in Stockholm and Göteborg during the 1940s and 

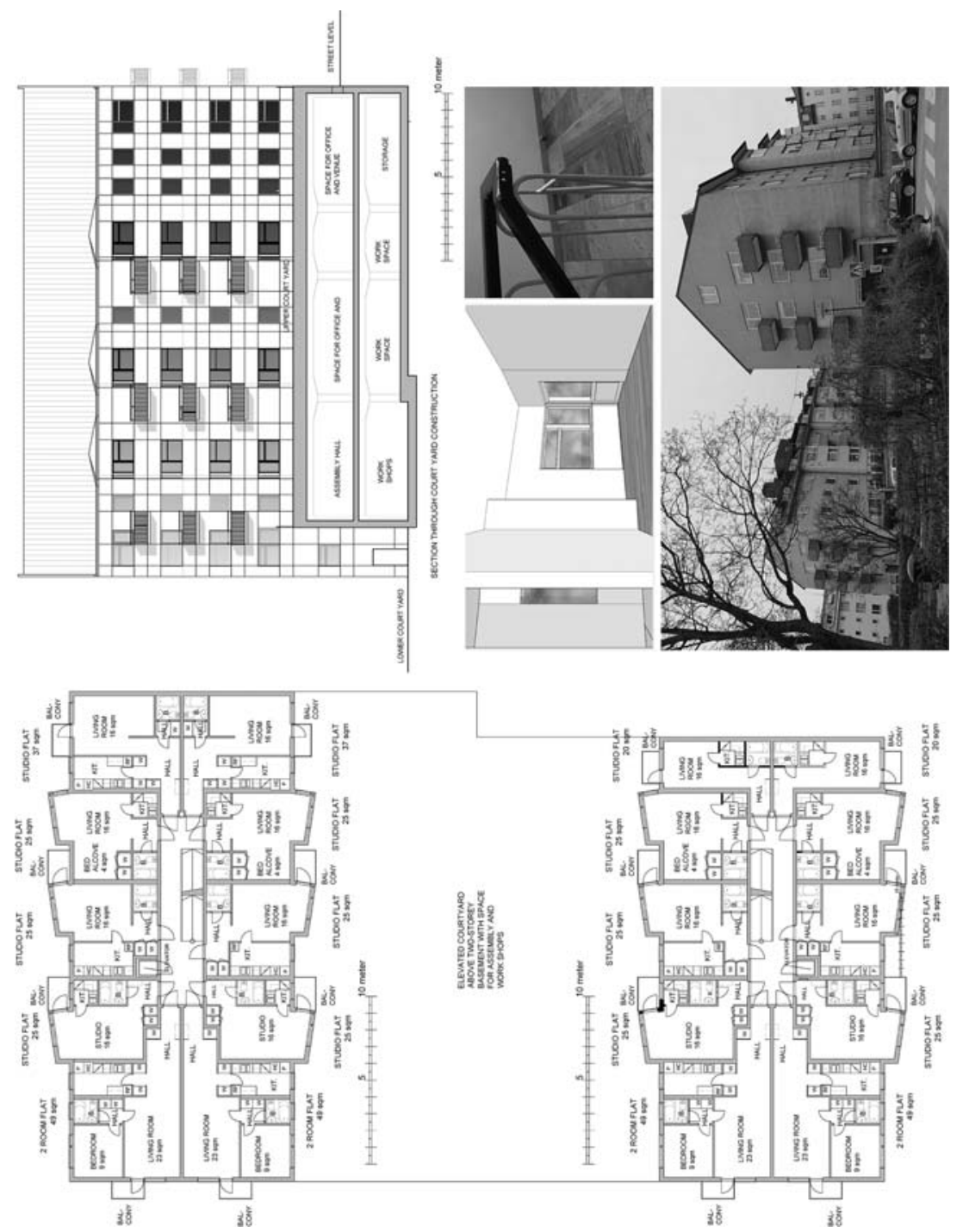

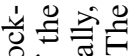

के

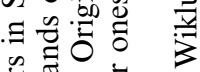

닝

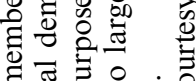

$\exists$. 준

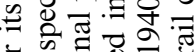

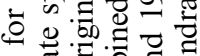

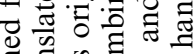

䒕:气 今0

훙ㅎㅇ

I 0

क

o. $\exists$.

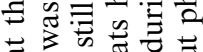

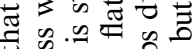

I

n.

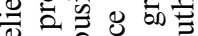

讨

我.

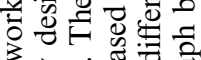

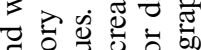

ส

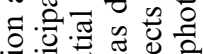

政

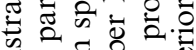

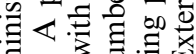

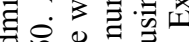

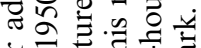

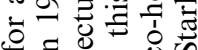

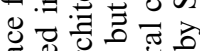

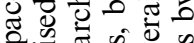

कि.

픈 원

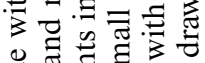

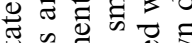

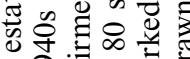

- 0 윰

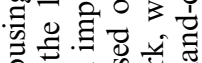

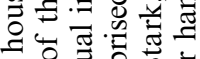

o 0 .

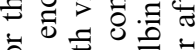

웅.

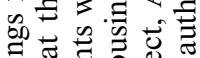

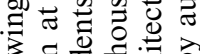

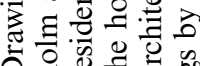

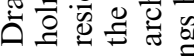

i

$\cong$

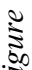
要 
1950s (Wiklund, 2018). In Stockholm, the settlement was located to the south of the inner city, near access points for buses, trains and metro lines. The configuration of the individual flats centred on visually impaired persons' ability to perceive space through touch and hearing, but also on how much daylight they got. Executed in a functionalist architecture, with two high-rise towers containing living spaces and a large top-lit ground floor with an assembly hall and meeting facilities (originally workshop spaces), the SRF settlement still exists today.

\section{Rethinking building design through systematic measurements}

The Stockholm Exhibition of 1930 boosted a drive to rethink contemporary problems and to innovate in the building industry. Using increased premanufacturing, rationalisation and new building techniques, the initiative involved architects' offices, housing estate companies and the building industry (Nordlander Finn, 1994). It also proposed a standardisation of building elements based on a deepened knowledge of users and user needs. The initiative included a research project which compiled human biometrics and mapped typical household manoeuvres. This aimed at establishing biometrical information on the interactions between a fully abled user and the built environment. Converted into minimum physical requirements for architectural designs, this was intended to produce break-even calculations that minimised building and production costs. In 1939, merging the existing Swedish tradition of high-quality arts and crafts products with the mass production orientation in architecture and everyday goods, the National Association for Arts and Crafts products (Svenska Slöjdföreningen, SSF) and the Swedish Architects (Svenska Arkitekters Riksförbund, SAR) initiated a joint venture to explore the constituents of the ideal home environment: the socalled Swedish Architects and Arts and Crafts Housing Inquiry (SAR:s och SSF:s Bostadsutredning) (Mattsson, 2010). This was the beginning of a 21year project that produced a series of reports on appropriate housing design, furniture design and which mapped national habits and the usage of the home environment.

The Swedish Architects and Arts and Crafts Housing Inquiry project assumed a sociological research approach, with a hands-on perspective on activities in daily living. The project accumulated research data through interviews, in situ evaluations and full-scale try-outs with voluntary participants, i.e. real-life users (Müller, 1951; Nordlander Finn, 1994). The different movements and adjustments for performing regular household chores were converted into physical measurements that were assembled into charts (see Figure 12.2). The charts described different sizes of dwellings in terms of physical measurements (Nordlander Finn, 1994). The spatial requirements for a standing person to perform food preparation on a counter and other household chores were assembled into national standards for kitchen cabinetry and wardrobe units (ibid.). The measurements considered the user's height in relation to the counter, capacity to move about and to reach and 

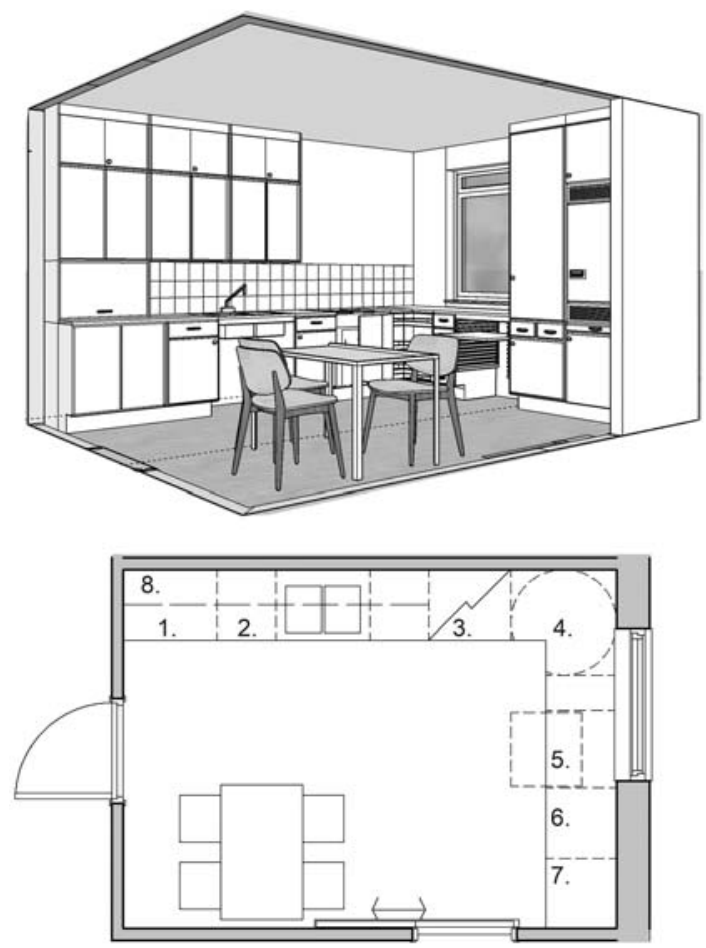

LEGEND:

1. Sideboard cabinet

2. base cabinet with counter for sink

3. stove with oven

4. corner cabinet with revolving shelves

5. moveable counter for household chores

6. pantry

7. refrigerator in raised position

8. upper cabinets

Most cabinets have sliding doors

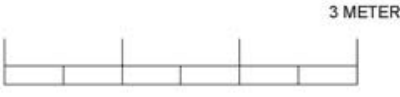

SCALE

Drawings and views based on material from a public inquiry SOU 1957:31, redrawn by author.

Figure 12.2 Spatial requirements for an adapted kitchen for people with locomotory and respiratory problems, e.g., knee space under the kitchen sink, a corner cabinet with rotating shelves, an adjustable workspace with pull-out counter and a refrigerator adjusted to persons using wheelchairs. The requirements were included in an appendix to the public report SOU Figure by author. 1957: 31 on appropriate housing for people with disabilities.

stretch for different operations and utensils. Soon, the project detected userrelated aspects that challenged the preconceived idea of a household with two adults and two children. The research discovered that an average family often included a person who had special needs due to disabilities that resulted in spatial adaptations, often locomotory, respiratory or visual problems. These findings led the National Association for People with Disabilities (Svenska Vanförekommittén), formed in 1911 and consisting of representatives of the seven major organisations for people with disabilities, to join the project in 1943 and take an active part in establishing spatial adaptations of the physical environment to meet the needs of this group of users (Müller, 1951). The needs were mainly linked to the consequences of poor work environments and the low standard of housing, and related to different forms of acquired disabilities with subsequent physical limitations (SOU, 1957: 31). Often, they related to locomotory limitations or visual problems after work-related 
injuries that required assistive equipment such as a cane or wheelchair. These needs could also refer to problems relating to the lungs and blood pressure due to inhalation of hazardous materials at work or following recovery from tuberculosis.

The spatial requirements which the research project generated also served as guidelines for state grants for improving housing standards in new and existing housing. These grants were allocated to 'families who due to medical reasons had a pressing need for improved housing' (SOU, 1957: 31, pp. 1011). The intended applicants were families in which one or several members suffered from rheumatism, tuberculosis or physical disabilities (ibid.). The guidelines covered both the location of the dwelling and its architectural design, and foregrounded the relationship between the user and the layout of the dwelling (Regeringen, 1958). The grants proved important for elucidating another topic that was much debated during the 1950s: appropriate housing for the elderly. Following a retirement reform in 1948, the prototype for old people's homes, according to the floorplans for institutions under the reform of the poor relief act in 1918, was subject to severe criticism by retirement organisations (Lo-Johansson, 1952). In the end, existing homes were simply converted into ordinary housing for frail older people in need of non-medical assistance and caregiving. Following the reforms concerning eldercare during the 1950s, in 1959 the state introduced subsidies for adapting the home environment for older persons with locomotory, respiratory and visual problems. During the 1960s, these so-called temporary invalid housing allowances were converted into a permanent system of adaptation allowances for older people with agerelated disabilities in 1963 (SOU, 1964: 41). Between 1965 and 1975, the allowances went from including only people with locomotory and respiratory problems to also including cognitive and hearing problems.

\section{Turning the building legislation into a socio-political instrument}

Besides the entrepreneurial response, the Stockholm Exhibition in 1930 also led to reforms of the building act. Until 1940 the existing building act, which stemmed from the latter part of the nineteenth century, had been updated by four consecutive reforms (Boverket, 2007). Two reforms pertained to the municipalities' responsibility for physical planning on a comprehensive and detailed level. The two subsequent reforms concerned building requirements for new housing. The reforms supported a more functional type of physical planning process in the larger city regions, to meet the increasing influx of new inhabitants from the countryside. In retrospect, the Stockholm Exhibition, in combination with the social-democratic dominance, in the 1932 elections, favoured the socio-political dimensions of an improved housing standard. Three years after the exhibition, the government assigned a parliamentary committee to explore the characteristics of the Swedish housing market (Nordlander Finn, 1994). From 1933 to 1947, the so-called Housing and Social Issues Committee (Bostadssociala Utredningen) analysed the 
national housing situation, the housing standard, demographics and socioeconomic data (ibid.). The committee concluded that most existing housing lacked space and facilities for food preparation, appropriate spaces for sleeping and hygiene installations like running water and water closets. In the construction of the Folkhemmet, i.e., the modern Swedish welfare model, the committee saw improved housing standards as key components of prosperity and public health.

During the 1930s and 1940s, two other parliamentary committees continued to analyse building costs, housing and town planning (Boverket, 2007). The shared motivation was to incite changes to the building act and address the poor standard of housing. Preparations for larger state investments in new housing, which would eventually become the Million Programme, were also drawn up (Boverket, 2007). In its final report, the committee proposed a new housing mortgage system which came into force in 1948 (Boverket, 2007). The mortgage system started to implement requirements for upgrading existing housing and producing new housing according to the national goals of the housing policy, based on the findings of the Swedish Architects and Arts and Crafts Housing Inquiry in 1939-1959. It allowed for the installation of heating, new materials, sanitation and running water in existing housing. To be eligible for these loans, the applicants had to be the owner or tenant of a flat, and the target group comprised average persons without disabilities (SOU, 1964: 41). Retired older persons could also apply for adaptations of their flats due to disabilities caused by age- or work-related problems (ibid.). During the 1950s, attention to the relationship between users and architectural design started to expand to also include the living conditions of people in institutions. The struggle to achieve their full inclusion in society gained momentum, mainly thanks to the sports movement for people with disabilities which promoted the so-called normalisation principle (Nirje, 1992).

During the 1950s and the first half of the 1960s, further work prepared for the inclusion of other findings from the Housing Inquiry project (SOU, 1964: 41). The committee report clearly associated the word 'accessible' with the needs of people with disabilities (Regeringskansliet, 1966). The majority of key stakeholders also consented to new physical requirements for more equal access to buildings, but which buildings and to which extent caused disagreements (ibid.). In the governmental bill, the focus was tightened to include mainly people with acquired disabilities. The then-minister of communication, Olof Palme, wrote in the government bill to reform building legislation:

Although the situation of people with disabilities has changed for the better in recent years, mainly through the addition of technical assistive equipment to help them to adjust to the surrounding environment, there is undoubtedly much to be done when it comes to adapting the environment to the special needs of people with disabilities.

(Regeringskansliet, 1966) 
In 1966, a new paragraph was introduced in the building act. The paragraph stipulated that public buildings were to be 'accessible' to a reasonable extent for 'people whose mobility is reduced due to age, impairment or disease' (SFS, 1966: 175). In the building regulations of 1968, the paragraph was reinterpreted to target so-called 'wheelchair users' (Statens Planverk, 1967). Besides the functional requirement for maintenance, accessible referred to sufficient access conditions for people with disabilities. The word 'accessible' became synonymous with the requirement to create 'reasonable access conditions' in various types of buildings (ibid.). In 1969, a set of physical requirements for accessible housing were published based on try-outs in full-scale laboratories at the national technical universities in which fully able-bodied students participated as test subjects (Statens Planverk, 1969). Minimum room sizes for accessible bathrooms and toilets in public building, hospitals and housing were specified (SPRI, 1979).

\section{Forging accessibility as a concept for equal access and inclusion}

In 1959, national Swedish radio broadcast a documentary on living conditions for children with disabilities at an institution in Stockholm (Asklund, 1959; Olsson, 2015). The documentary was considered as an infamous attack on a renowned institution, founded by a member of the royal family and enjoying state support (ibid.). The minister for social affairs questioned the journalistic interest in such housing and called for censorship. The documentary raised a public outcry against the inhumane and restrictive living conditions at institutions for young people with disabilities. A parliamentary committee was formed to explore living conditions for people with disabilities who were accommodated at public institutions (SOU, 1967: 53). The committee confirmed systematic abuse by the staff of admitted children and adolescents and concluded:

The needs of people with disabilities have to be taken into consideration everywhere in society: in social planning, in the production of new housing, in education and at the labour market, in the national insurance system and in cultural activities.

(SOU, 1967: 53)

The documentary resulted in a new law that gave the right to national radio to broadcast critical documentaries on societal matters. Private initiatives started a funding campaign to organise an architectural competition on appropriate housing, so-called Fokus houses (see Figure 12.3), for young people with disabilities (Brattgård et al., 1972; Wallsten, 2013). Architecture students at the national technical universities were eligible to participate. The competition defined spatial requirements for designing appropriate flats within ordinary housing for people with disabilities. During the 1970s, some 700 flats of this type were built, mainly in smaller municipalities (ibid.). The building costs and management of the houses were sponsored to about 55 per 

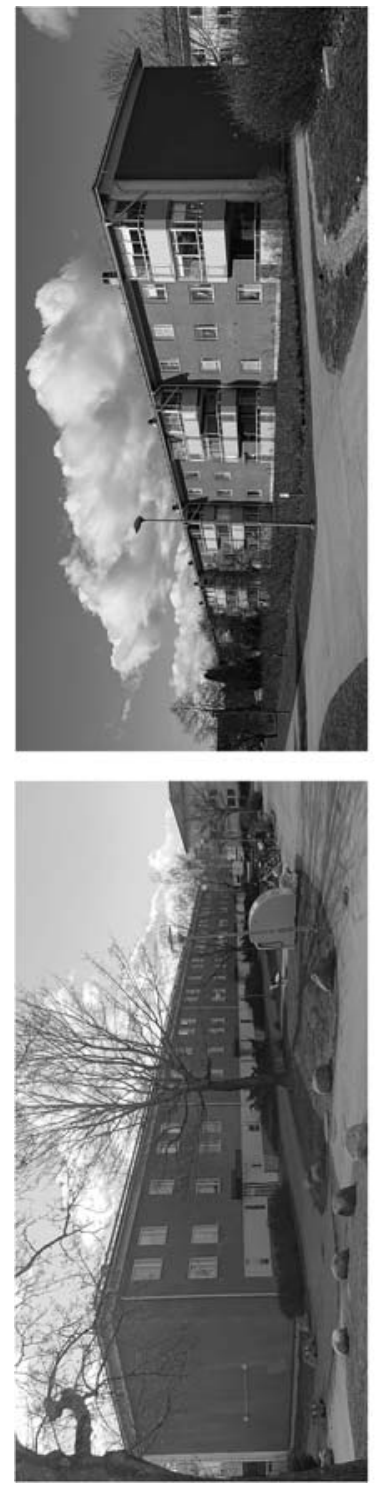

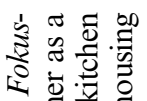
릉 तु 这

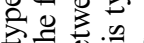
웡

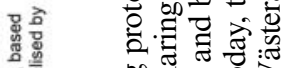

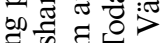
की की o

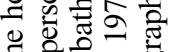
$\exists=20$

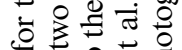

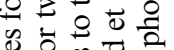

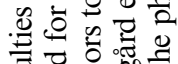
उ. 空

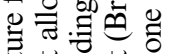
证:

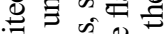

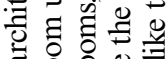
(5)

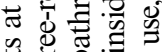

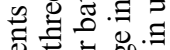
空

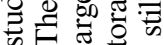
का 过. 䜣 昰. 政

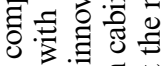

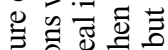
㣢总昰. 要

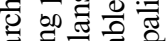
要

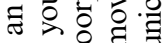
$\Xi$ 후의 웡워 융 웅 물 귱 음. 중 प

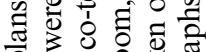
늉 वे 응 항 일

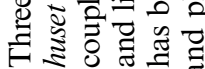

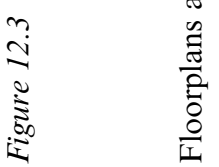


cent by the disability movement, while municipalities and regions financed the rest. Today, this type of housing is fully financed and provided by the municipalities, since legal reforms have integrated this type of housing within the municipal care and support for persons with disabilities and older people that started to develop during the 1980s (see Figure 12.3).

In 1971, the building act was once again up for reform. This time, the reform introduced accessibility as a minimum requirement for both housing and public buildings. In the new building legislations, accessibility requirements for architecture and planning came under the common concept of 'accessibility' which was specifically defined as parameters that gave equal access to the built environment. The intended group of users was broadened from people using wheelchairs to include other users who experience 'cognitive problems to navigate in space' (Regeringen, 1971). Consequently, this reform also demanded an update of existing building regulations. The new regulations used the requirements for housing that the housing mortgage system activated for the design of the Million Programme in 1965-1975. The close connection between the building regulations and the housing loan system guaranteed the full implementation of the requirements in buildings from 1976-1989 (Statens Planverk, 1975). Later, these requirements were converted into national standards on appropriate design solutions for housing that concerned minimum specifications for comfortable width of passage, number of storage units, kitchen cabinetry and other accessibility measurements.

With its appurtenant building regulations, the building act of 1971 realised the goals that the parliamentary commissions of the 1940s had formulated: an improved Swedish housing standard with general high quality in housing promoted by state loans and subsidies for home adaptations. However, negative views of the Million Programme architecture - people generally regarded it as high-rise buildings in sterile settlements - anticipated the end of functionalist architecture as a socio-political instrument.

The investment in the Million Programme housing proved that large-scaled planning projects with limited user influence could lead to social problems and stigma (Pech, 2011). During the 1980s, a new type of two-storey residential architecture was produced instead, in which the ground floor was larger to supply accessible surfaces in case of need due to disabilities. In a similar way, the prioritisation of municipal and state interests over the financial investments of private homeowners or property developers suggested that the building legislation was out of step with societal evolution. The building legislation generated a strong public criticism and preparations were made to fundamentally reform the building act (SFS, 1987: 10, 1987). Promoted by the housing loan system and specified building regulations, the concept of accessibility was especially vulnerable to changes.

A new building act was introduced in 1989. The paragraph on accessibility in housing and public buildings was kept, and was identical to the wording used in 1971 (SFS, 1987: 10). However, in this new structure, which had non-binding minimum requirements in appurtenant regulations, accessibility as a spatial requirement became void (Boverket, 1988). As a quick remedy to the apparent 
lack of influence on the built environment, the newly formed authority in charge of building and planning matters, the Board for Housing, Building, and Planning, commissioned a set of minimum guidelines for accessibility in the built environment from the Swedish Institute for Assistive Technology, which had been established in 1968 to replace a previous organisation from 1911 and was co-owned by municipalities and the Swedish state. This resulted in a publication entitled 'Build up more accessibility' which assembled accessibility requirements from 1965-1989 and supplied explanations with drawings and illustrations (Svensson, 2015). This publication instantly filled the evident void in the legislation on the fit between people with disabilities and the built environment, and was embraced by architects and building companies as an easy guide to accessibility. The success of the publication continues. It is regularly updated, with the latest edition released in June 2020. In all probability, this is the number one Swedish guidebook on accessibility and spatial needs for people with disabilities, not only for the building industry, but for other stakeholders that plan and distribute care, nursing, and support to people with disabilities and older persons.

\section{Consolidating accessibility through agreements and standards}

The inconsistencies regarding accessibility requirements in the new building act of 1989 were partly because this reform coincided with the work of an ongoing parliamentary committee on living conditions for people with disabilities (SOU, 1991: 46). In its final report issued in 1992, the committee made several proposals concerning the built environment to improve living conditions for people with disabilities (ibid.). The committee suggested that retrofitting the existing built environment to modern accessibility requirements should also be regulated by the building act (SOU, 1992: 52). In addition, the Swedish acceptance in 1993 of the 22 UN Standard Rules on the Equalization of Opportunities for Persons (United Nations, 1993) prepared for a revision of building regulations that adhered to the new building act. In 1994, the Board for Housing, Building, and Planning issued new building regulations which were a complete makeover of the five-year old legal framework and integrated accessibility requirements introduced during the 19661989 period (Boverket, 1993). Once again, accessibility requirements were explicitly linked to users with 'wheelchairs or [who] experience cognitive difficulties in navigating in space' (BFS, 1993: 57). The idea of retrofitting existing buildings to modern accessibility requirements generated some concerns within government, and a committee was assigned to explore the matter further (SOU, 1994: 36).

The committee concluded that public buildings often present physical barriers for people with disabilities, which could prevent their participation in society. Physical barriers that created accessibility problems were therefore identified and targeted for removal on a continuous basis (SOU 1994: 36). The 1990s saw several initiatives to remove physical and perceived societal barriers for the inclusion of people with disabilities. In 1992 the old system, 


\section{2}

with state grants for home adaptations for disabilities, was reformed (SFS, 1992: 1574). Two other laws on the remuneration of assistants to persons with disabilities and special support and services for people with disabilities were introduced. In 1995, large institutions for people with mental health issues were dissolved and replaced by group living within the ordinary stock of residential housing (SOU 1992: 73). In 1999, a new law on discrimination against people with disabilities in the labour market came into force (SFS, 1999: 130). The new disability policy for the period of 2000-2010 combined these disparate improvements into a ten-year plan for realising the elimination of physical barriers and promoting equal opportunities for all people (Regeringen, 2000a). The building act was reformed to add a paragraph on eliminating so-called easily removable obstacles in public buildings and the public space (Regeringen, 2000b). Requirements on signage and contrast markings in the built environment were introduced (ibid.).

International agreements also highlighted accessibility as an essential right of people with disabilities. In 2008, the CRPD was opened for signatures and ratification (SÖ 2008: 26). The convention raised the matter of accessibility to be usable by a multitude of users and identified the design of the built environment and other specific artefacts as a key element of effective accessibility. Sweden's accession to the convention in 2008 also had an impact on the building act. In the revision of the act and appurtenant regulations, accessibility became part of the new twin concept of 'accessibility and usability'. Since 2010, this twin concept has guided requirements for the architectural design of new and existing buildings without barriers for people with disabilities. As a member of the European Union, Sweden is also part of the EU disability policy programme. In 2010, the European Union established an annual competition, the so-called Access City Award which invites cities with over 50,000 inhabitants to apply to be recognised for their work in making the built environment more accessible and increasing inclusion and participation for people with disabilities (European Commission, 2010).

The period between 2000 and 2011 was also distinguished by international projects that confirmed the link between accessibility requirements in the built environment and the rights of people with disabilities. In response to the ageing population, a guide for manufacturers of different products, the so-called Guide 6, was assembled the International Organisation for Standardisation. Later, another project assembled the international standard for accessibility and usability requirements in the built environment, ISO 21542 (currently under revision). As part of the European disability policy, the European Union is preparing an EU act on accessibility in the public environment which will be implemented by each member state and will require a European standard on accessibility and usability in the built environment. The European standardisation work started in 2017 with a special project group of experts which compiled draft accessibility requirements. After an intense discussion with member-state representatives, the EN 17210 standard was accepted in October 2020. 


\section{Accessibility: a responsibility shared between multiple stakeholders}

The previous sections have traced the history behind the accessibility requirements of the Swedish building act today. The search for adequate space for a large variety of users in different types of built environments can largely be attributed to the over-arching ambition of constructing appropriate housing at reasonable cost by controlling the square-metre area of the habitat. From 1930 onwards, this ambition has been associated with an aesthetic orientation in building design, i.e. with functionalist architecture. What was originally an initiative of the building market has become a shared interest for investors and society. Over the past 90 years, the minimum spatial requirements for the built environment to be at least partly usable for people with disabilities have been defined and integrated in the professional knowledge of architects and other building experts, but also the legislators behind the building act. The requirements provide a minimum level of accessibility and usability that can be further adapted to personal needs through individualised assistive devices. Through full-scale try-outs in spaces for different usages, the requirements have gone from being random minimum measurements and loose recommendations into hard regulations with which the built environment must comply. National and international standardisation confirm their validity.

This retrospective suggests there has been a conscientious and altruistic ambition by actors in the Swedish building market - architects, building companies and building material suppliers - to define guidelines to eradicate the poor housing situation in Sweden. Analogous to industrial production, the underlying idea has prioritised rationality, systemisation, and standardisation in creating appropriate housing for citizens, with modern hygiene and ventilation. The totality of the measurements falls into the category of minimum requirements that primarily promote the interaction of fully abled bodies with the built environment. By doing so, and without alternative studies, the Swedish building market has assumed that people outside this category can also be accommodated. Measurements including people outside the original intended group have been established as part of the overall quest for acceptance of people with disabilities in society by organisations that defend equal rights regardless of ability. These organisations have initiated and financed parallel studies on impairment and the use of built space. Adopting the same test methods as the building industry in their studies, the fundamental criterion has been to define minimum threshold values for various interactive situations: passing through a doorframe with a wheelchair, progressing up a ramp or crossing the threshold of a door with a cane or wheelchair.

However, it was neither the Swedish building market nor the non-governmental organisations that connected the dots and suggested a strategy for implementing new findings on the minimum fit between the built environment and human beings with all their diversity. Coinciding with other preparations 


\section{4}

for a political overhaul of the (then-embryonic) Swedish welfare regime in the 1930s, minimum requirements for the built environment were integrated into a comprehensive socio-political strategy to establish an egalitarian welfare model, the Folkhemmet. Minimum requirements for housing and public buildings were put into practice through the building act in combination with state subsidies and a housing loan system which lasted until 1989. This implementation occurred in parallel with a shift in cultural and social beliefs during the 1960s: the normalisation principle, which gradually allowed people with disabilities to be included in society on equal terms (Nirje, 1992). This combination of initiatives, originating in the building market, disability organisations and the state's legislative implementation, has been an important asset in realising inclusion in a modern welfare society. Paired with design and technical developments in assistive technologies, the minimum requirements for the built environment can be surmounted further through individually adjusted assistive equipment, thus further lowering the barriers to full inclusion. However, it is an open question whether minimum accessibility requirements will continue to regulate the built environment for the greater good of all citizens since, in the current disability policy, the concept of universal design supersedes accessibility and inclusion.

\section{Conclusion: accessibility requirements today}

Given the background described above, and the consistent evolution since the 1930s of spatial requirements to equip both existing and new buildings with a minimum level of accessibility and usability for people with disabilities, it is problematic, to say the least, that the building market criticises the legislative system that has resulted for Swedish building as obsolete, cost-generating and time-consuming (Fock, 2010; NCC, 2012; Nohrstedt, 2009). Already back in the 1980 s, building requirements, especially accessibility requirements, were said to be too far-reaching and as having a restricting effect on building design (ibid.). Regardless of their political orientation, four recent governments between 2006 and 2020 (of these two were left-wing and two right-wing governments) have lent a keen ear to the claims of the building industry. This attention is mainly motivated by ongoing demographic changes and permanent housing shortages since the 1990s, which have particularly affected young people, older persons and people with disabilities (Boverket, 2021). In consequence, the building act has been revised multiple times since 2010 and building regulations were updated 12 times between 2011 and 2020. The government also assigned a committee to investigate allegations that identical building prototypes generated different production costs around Sweden. In 2020, the committee concluded that the problem revolved around the fact that the 290 Swedish municipalities in accordance with the local government act formulated their own requirements on types of housing and levels of accessibility and usability (SOU, 2020: 75). 
Attentive to the influential Swedish building industry, the government instructed the Board for Housing, Building, and Planning in 2019 to review the legal manner, in use since 1989, with which the authority formulates building regulations. According to the instruction, the government detected 'a need for a systematic review of the regulations for building and constructions' (Boverket, 2020). The intention of the review was to create a 'simplified and consequent framework with a similar structure and level of detailing'. At time of writing in early 2021, the board is rewriting, chapter by chapter, the building regulations so that each paragraph only gives a brief outline of necessary building requirements. Previous regulations included a section on recommendations and general advice which explained, in concrete and direct language, the practical understanding of the legal intent. This will be omitted. According to the board, the reason for this is:

The national Board for Housing, Building and Planning shall specify the requirements that are expressed in a law or an ordonnance, while the building market shall produce solutions that fulfil these requirements as well as methods to verify that the specified requirement is reached. The new model for writing regulations equips the building market with the prerogatives it demands and needs to be more proactive and assume responsibility for the challenges that the market is facing, e.g., sustainability and financial solutions. The building market has the expertise and can be assumed to distribute resources in a more efficient manner and be better at identifying which solution that needs further evolutive work.

(Boverket, 2020: 6)

This handing over of power from the state to the building industry to define the minimum level of accessibility for the built environment under which people with disabilities can enjoy full inclusion and participation seems hasty and poorly thought through. At best, it will reflect a conundrum in architecture, where examples of accessibility and usability of the built environment are perceived as exemplary models but are, in reality, an architectural rendering of time-related problems (Till, 2009). The change undermines a 90-year quest for improved living conditions for people with disabilities. The vital user-related perspective, which disability organisations have provided during the gradual development of accessibility requirements, is at risk of being forgotten and omitted.

As this chapter has shown, the building industry has always focused on minimum requirements that promote the fit of fully abled body with the built environment. Hitherto, the state has also had a strategy of bringing forward minority groups' demands on the built environment. The propulsion of universal design into becoming the prime objective for Swedish disability policy between 2016 and 2021 over accessibility and usability requirements risks creating a precarious future for people with disabilities. In the absence of minimum requirements defined by people with disabilities, it is yet to be seen if this new focus on universal design will promote ease of use for everyone, or if financial motives for the building market will supersede the matter of inclusion. 
Yet, there may be some reason to hope that the move to universal design as guideline could be a positive development. The vagueness of the concept in the Swedish context may reorient the understanding of requirements for accessibility or usability to ensure inclusion of people with disabilities away from being scarce minimum measurements into becoming design parameters for a new, socially sustainable, Swedish welfare state - inclusion for all, regardless of age or disability.

\section{References}

Asklund, Lis (1959) Reportage om Eugeniahemmet. Stockholm: Sveriges Radio.

Asplund, Gunnar, Gahn, Wolter, Markelius, Sven, Paulsson, Gregor, Sundahl, Eskil \& Åhrén, Uno (1931) Acceptera. Stockholm: Tidens förlag.

Åman, Anders (1976) Om den offentliga vården. Byggnader och verksamheter vid svenska vårdinstitutioner under 1800- och 1900-talet. Stockholm: LiberFörlag \& Sveriges Arkitekturmuseum.

Bergh, Anders (1996) Vad döljs bakom "hemlikhetens vind" In David Gaunt \& Göran Lantz (Eds.), Hemmet $i$ vården, vården $i$ hemmet. 121-135. Stockholm: Liber Förlag/Ersta vård-etiska institutet.

BFS (1993: 57) Boverkets Byggregler BBR. Karlskrona: Boverket.

Boverket (1988) Boverkets Nybyggnadsregler, NR. BFS 1988:118. Karlskrona: Boverket.

Boverket (1993) Boverkets Nybyggnadsregler, NR4. BFS 1993:26. Karlskrona: Boverket.

Boverket (2007) Bostadspolitiken. Svensk politik för boende, planering och byggande under 130 år. Boverket.

Boverket (2020) Möjligheternas byggregler. Ny modell för Boverkets bygg- och konstruktionsregler. [Regulations for possibilities]. Karlskrono: Boverket. https://www. boverket.se/globalassets/publikationer/dokument/2020/mojligheternas-byggregle r-ny-modell-for-boverkets-bygg-och-konstruktionsregler.pdf (Accessed 8 March 2021).

Boverket (2021) Bostadsbehov för särskilda grupper. Boverket. https://www.boverket.se/ sv/kommunernas-bostadsforsorjning/underlag-for-bostadsforsorjningen/sarskilda -grupper/ (Accessed 8 March 2021).

Brattgård, Sven-Olof, Carlsson Folke, Hammerin, Karl-Erik, Nilsson, Helmer \& Sandin, Arne (1972) Bostad och service for svårt rörelsehindrade: Redogörelse för Stiftelsen Fokus verksamhet. Stockholm: Nordiska Bokhandeln.

Civildepartementet (1920) Normalritningar till ålderdomshem, barnhem, mm. Stockholm: Civildepartementet.

Cold, Birgit, Dunin-Woyseth, Halina, \& Sauge, Birgitte (1992) Om arkitekturforskning og arkitekturforskningslandskapet i Norge 1992. Nordisk Arkitekturforskning (2): 8-19.

Dion, Betty, Pineda, Victor, \& Ginnerup, Sören (2015) Toolkit: Key Indicators of Accessibility: Reporting on the UN CRPD for the Delta Centre, Norwegian Directorate for Children, Youth and Family Affairs. http://gaates.org/wp-content/uploads/ 2014/07/FINAL-Toolkit_-UN-CRPD-KEY-INDICATORS-OF-ACCESSI BILITY-2015-06-29.pdf (Accessed 8 March 2021).

Eriksson, Eva (2001) Den moderna staden tar form: arkitektur och debatt 1910-1935. Stockholm: Byggförlaget i samarbete med Arkitekturmuseet.

European Commission (2010) Access City Award 2020. https://ec.europa.eu/social/main. jsp?langId=en\&catId=1141\&eventsId=1442\&furtherEvents=yes (Accessed 8 March 2021). 
Fardeau, Michel (2015) Conference on Research on Accessibility (Speech). Paris: Délégation Ministérielle d'Accéssibilité.

Flyvbjerg, Bent (2004) Five Misunderstandings About Case-study Research. In C. Seale, G. Gobo, J. F. Gubrium, \& D. Silverman (Eds), Qualitative Research Practice (pp. 420-434). Thousand Oaks, CA: Sage.

Fock, Johan (2010) För hårda krav på tillgänglighet. Byggvärlden, November (2010). http s://www.byggvarlden.se/for-harda-krav-pa-tillganglighet-60657/nyhet.html (Accessed 8 March 2021).

Foucault, Michel (1975) Surveiller et punir. Paris: Gallimard.

Gieryn, Thomas F. (2002) What Buildings Do. Theory and Society, 31 (1): 35-74.

Goffman, Erving (1961) Asylums: Essays on the Social Situation of Mental Patients and Other Inmates. London: Penguin Books.

Göransson, Viking, \& Sundbärg, Göran (1933) Ålderdomshem i Sverige. Byggmästaren, 26: 133-141.

Hansson, Per-Albin (1928) Folkhemstalet i Sveriges Riksdag den 18 januari 1928. Stockholm: Sveriges Riksdag. http://www.svenskatal.se/1928011-per-albin-hanssonfolkhemstalet/ (Accessed 8 March 2021).

Hill Collins, Patricia, \& Bilge, Sirma (2020) Intersectionality (2nd edition ed.). Cambridge: Polity Press.

Hong Rutt, Anna (1933) Why Sweden leads in design. The American Magazine of Art, 26(4): 169-180. https://www.jstor.org/stable/23954973 (Accessed 8 March 2021).

Kolstrup, Sören (1996) Velfaerdsstatens roedder: fra kommunesocialisme til folkepension. Copenhagen: SFAH.

Lo-Johansson, Ivar (1952) Ålderdoms-Sverige. En stridsskrift. Stockholm: Bonniers förlag.

Lundberg, Urban, \& Tydén, Mattias (2010) In Search of the Swedish Model, Contested Historiography. In Helena Mattson \& Sven-Olov Wallenstein (Eds), Swedish Modernism. Architecture, Consumption and the Welfare State. Stockholm: Black Dog Publishing.

Mattsson, Helena (2010) Designing the Reasonable Consumer. Standardisation and Personalisation in Swedish Functionalism. In Helena Mattson \& Sven-Olov Wallenstein (Eds), Swedish Modernism. Architecture, Consumption and the Welfare State. Stockholm: Black Dog Publishing.

Müller, Henrik (1951) Bostäder för vanföra. Svenska Vanförevårdens Centralkommitté.

NCC (2012) Fånga tidstjuvarna och bygg bort bostadsbristen. Stockholm: NCC Communications.

Nirje, Bengt (1992) The Normalization Principle and its Human Management Implications. In B. Nirje (Ed.), The Normalization Principle Papers (pp. 18-25). Uppsala: Uppsala University.

Nohrstedt, Linda (2009) JM kritiserar byggreglerna. Byggvärlden, Maj (2009). https:// www.byggvarlden.se/jm-kritiserar-byggreglerna-62238/nyhet.html (Accessed 8 March 2021).

Nordlander Finn, Annika (1994) Byggforskningens organiseras 1900-1960. Stockholm: Byggforskningsrådet.

Norris, Adele N., Murphy-Erby, Yvette, \& Zajicek, Anna M. (2007) An Intersectional Perspective in Introductory Sociology Textbooks and the Sociological Imagination: A Case Study. Race, Gender \& Class, 14 (1-2): 333-344.

Olsson, Rigmor (2015) Radiofynd: Eugeniahemmet 1959. Stockholm: Sveriges Radio. 
Pech, Christina (2011) Arkitektur \& Motstånd. Om sökandet efter alternativ i svensk arkitektur 1970-1980. Doktorsavhandling. Stockholm: Kungl. Tekniska Högskolan, KTH.

Persson Bergvall, Inger, \& Sjöberg, Malena (2012) Aratal - ur handikapphistorien. Stockholm: HandikappHistoriska Föreningen. media1.hhf.se/2015/03/aratal_ur_ha ndikapphistorien.pdf (Accessed 8 March 2021).

Proposition (2016/17: 188) Nationellt mål och inriktning för funktionshinderspolitiken. Stockholm: Regeringskansliet.

Regeringen (1958) Kungl. Maj:ts proposition till riksdagen agnående anslag för budgetåret 1958/59 till främjande av bostadsförsörjningen m. m. (Prop. 1958:119). Stockholm: Regeringskansliet.

Regeringen (1971) Kungl. Maj:ts proposition med försIag till kungörelse om ändring $i$ byggnadsstadgan (1959:612). Prop. 1971:48. Stockholm: Regeringskansliet.

Regeringen (2000a) Från patient till medborgare. En nationell handlingsplan för handikappolitiken. Proposition 1999/2000:79. Stockholm: Regeringskansliet.

Regeringen (2000b) Tillgänglighet till offentliga lokaler och på allmänna platser. Regeringens prop. 2000/21:48. Stockholm: Regeringskansliet.

Rudberg, Eva (1999) Stockholmsutställningen 1930: modernismens genombrott $i$ svensk arkitektur. Stockholm: Stockholmia förlag.

Schön, Donald (1988) Designing: rules, types and worlds. Design Studies, 9 (3): 181-190.

SFS (1992:1574) Lag om bostadsanpassningsbidrag m.m. Stockholm: Statens Författningssamling.

SFS (1999:130) Åtgärder mot diskriminering i arbetslivet på grund av etnisk tillhörighet, religion eller annan trosuppfattning. Stockholm: Statens Författningssamling.

SFS (1966:175) Byggnadsstadgan, SFS 1966:175. Stockholm: Statens Författningssamling.

SFS (1987:10) Plan- och Bygglagen, PBL. Stockholm: Statens Författningssamling.

SFS (2010:900) Plan- och Bygglagen, PBL. Stockholm: Statens Författningssamling.

Svenska Institutet för Standarder (2021) Tillgänglighet och användbarhet $i$ byggd miljö. SIS/TK 453. Stockholm: Svenska Institutet för Standarder. https://www.sis.se/standa rdutveckling/tksidor/tk400499/sistk453/ (Accessed 8 March 2021).

SOU (1957:31) Bostäder för åldringar och invalider. Förslag till stödåtgärder avgivna av Bostadspolitiska Utredningen. Stockholm: Statens Offentliga Utredningar.

SOU (1964:41) Bostadsstöd för pensionärer. Förslag av Bostadsförbättringsutredningen. Stockholm: Statens Offentliga Utredningar.

SOU (1967:53) Kommunerna och den sociala omvårdnaden: rapport och förslag av Handikapputredningen. Stockholm: Statens Offentliga Utredningar.

SOU (1991:46) Handikapp, Välfärd, Rättvisa. Betänkande av 1989 års Handikapputredning. Stockholm: Statens Offentliga Utredningar.

SOU (1992:52) Ett samhälle för alla: slutbetänkande av 1989 års Handikapputredning. Stockholm: Statens Offentliga Utredningar.

SOU (1992:73) Psykiatrireformen. Stockholm: Statens Offentliga Utredningar.

SOU (1994:36) Miljö och fysisk planering. Delbetänkande från Plan- och Byggutredningen. Stockholm: Statens Offentliga Utredningar.

SOU (2020:75) Bygg och bo till lägre kostnad - förslag för bättre konkurrens $i$ bostadsbyggandet. Statens Offentliga Utredningar, Issue. Stockholm: Statens Offentliga Utredningar.

SPRI (1979) Hygienrum: utrymme för personlig hygien vid avdelningar för långvårdssjukvård. Stockholm: Sjukvårdens Planerings- och Rationaliseringsinstitut. 
Statens Planverk (1967) Svensk Bygg Norm, SBN 67. Föreskrifter, råd och anvisningar till byggnadsstadgan BABS 1967. Stockholm: Statens Planverk.

Statens Planverk (1969) Handikappbyggnormer: föreskrifter, råd och anvisningar om byggnaders tillgänglighet för personer med nedsatt rörelseförmåga. Stockholm: Statens Planverk.

Statens Planverk (1975) Svensk Bygg Norm 1975, SBN 75. Föreskrifter, råd och anvisningar för byggnadsväsendet utfärdade med stöd av 76 \& byggnadsstadgan Stockholm: Statens Planverk.

Story, Molly Follette, Mueller, James L., \& Mace, Ronald L. (2011) The Universal Design File: Designing for People of All Ages and Abilities. Design Research and Methods Journal, 1 (1). http://design-dev.ncsu.edu/openjournal/index.php/redlab/a rticle /view/102 (Accessed 8 March 2021).

Svensson, Elisabeth (2015) Bygg ikapp. För ökad tillgänglighet och användbarhet för personer med funktionsnedsättning (6e Utgåvan). Stockholm: Svensk Byggtjänst.

SÖ (2008:26) Nr 26. Konventionen om rättigheter för personer med funktionsnedsättning och fakultativt protokoll till konventionen om rättigheter för personer med funktionsnedsättning. New York den 13 december 2006. Sveriges Utrikesdepartement. http://www. un.org/disabilities/documents/convention/crpd_swedish.pdf (Accessed 14 April 2021).

Till, Jeremy (2009) Architecture Depends. Cambridge, MA; London, England: The MIT Press.

Wallsten, Anna (2013) Röda fjädern och fokushusen. Nordiska Muséet. http://media1. hhf.se/2016/02/R\%C3\%B6da-fj\%C3\%A4dern_v2.pdf (Accessed 14 April 2021).

Wiklund, Wim (2018) Tactile Architecture, on the Roots of Design for People with Visual Impairments. (Unpublished Material). NAAR/NAF Symposium 2018, Tampere, 31 May to 1 June.

Yin, Robert K. (2003) Case Study Research, Design and Methods. Thousand Oaks: Sage Publications. 